\title{
EK-WGI 法による山留め壁の作用外力の同定

\author{
IDENTIFICATION OF EXTERNAL FORCES ACTING ON RETAINING \\ WALL BY EK-WGI METHOD
}

\author{
斉藤 悦 郎*·古賀重利** \\ By Etsuro SAITO and Sigetoshi KOGA
}

\begin{abstract}
This is a report on a study of parameters estimation, such as lateral pressure acting on retaining wall and elastic constants of soil, etc, from measured data of the wall displacement (degree of rotation) during excavation. EK-WGI method which was developed based on the extended Kalman filter of controll theory was applied to the parameters estimation method. A feature of this method can be estimated recursively unknown parameters in the direction of the depth of retaining wall. In the analysis, simulated data which were used for verification of formulation to EK-WGI method was applied. From numerical results, it was clearly observed that this method was effective to estimate these parameters.
\end{abstract}

Keywords : identification, extended Kalman filter, retaining wall

\section{1.はじめに}

掘削工事において, 各掘削段階での山留め架構の挙動 を，計画・設計段階で十分検討されたとしても，施工中 の複雑な挙動を的確に推定することはきわめて困難であ る. 現在では, 大規模な掘削工事や都市密集地の悪条件 での工事が多くなり, 安全性の高い施工を進めるうえで, 施工中の挙動を的確に把握することが特に必要となって きている，この問題に対してテルツァギ一は，施工現場 において計測を実施することにより，計画・設計時と実 際との挙動の相違を補う Observational Procedure とい う考えを示している11.この考え方によれば, 次期施工 段階での挙動予測を現段階での現場計測値をもとに推定 できることから, 計画・設計時に予測した挙動と比較し て, より実際に近い予測值が得られるものと思われる.

山留め架構の施工中の挙動を把握するための計測項目 としては, 山留め壁の状態を知る, 壁体変位 (傾斜角) およびひずみ計测, また山留め壁に作用する側圧を知る, 土圧, 水圧および切ばり軸力の計測, がある.これらの すべての計測が可能である場合には，これらの計測値に

* 正会員 工博 フジタ工業(株)技術研究所土木施工研究室 ( 厂223 横浜市港北区大棚町 74)

** 正会員 フジタ工業(株)技術研究所土木施工研究室 (同上)
よる現掘削段階での現状評価およびこれらの計測值をも とにした次段階掘削時の予測が可能となる.しかしなが らこれらすべての計測を実施するには，かなりの費用 を必要とすることから，一般には，山留め壁の変位およ び切ばり軸力の測定を行い, 現在の状態が管理規準值内 であることの確認程度にこれらの実測值が用いられてい る. 本論文は, 山留め壁の変位の計測値から, 山留め壁 に作用する側圧等の推定法を示したものである.この推 定が可能であれば, 現掘削段階での外力の状態が明確に なるとともに，次段階掘削時の予测が推定結果をもとに 可能となり，上述で示したようにより実際に近い山留め 壁の挙動を知ることができる。また，側圧の計測も同時 に実施されている場合, 壁体変位からの側圧推定值は, 計測側圧との比較または対比といった 2 方向からの検討 に利用できる利点がある.

さてブラックボックスであるシステム（ここでは，山 留め架構）を通過した計測データよりそのシステムの状 態を推定するシステム同定は, そのシステムの構造モデ ルの同定と, その構造モデルを決めたことによって生ず る未知パラメーター同定とに分類できる. 特に, 構造モ デルが决められている場合にその未知パラメーターを推 定する方法は, 逆解析とよばれている. 逆解析の方法に は, 各種の方法が提案されているが, 大きく 2 つに分類 
することができる.すなわち数理計画法の最適化手法に よる決定論的方法とベイズ理論による確率論的方法であ る2). 現在まで山留め掘削工事において山留め壁の側圧 等を推定する方法として用いられている逆解析手法 ${ }^{3), 4)}$ は, 前者に属するものである. EK-WGI 法 ${ }^{5)}$ は, 拡張力 ルマンフィルター6)を基本式としていることから後者に 属するものである.一般に現場計測による計測デー夕は， データ自身のばらつきが大きく，これらのデータに基づ く逆解析法としては，確率論を基本においた考え方がよ り適したものと思われる.

一方逆解析における対象構造モデルの定式化には，直 接定式化法之逆定式化法がある．直接定式化法は，特別 な定式化を用いず, 逆解析が可能であり, 多くの逆解析 問題に適用できる特徵がある，逆定式化法は，対象構造 モデルごとに定式化が必要であるが，計算時間は，直接 定式化法に比べ一般にかなり短縮できる.

山留め架構の構造モデルに対する定式化法は，その逆 定式化が困難であるため，直接定式化法が用いられてい $3^{4)}$.

ここで対象とする作用外力の同定によって得られる結 果は, 次段階掘削時の予測計算に用いる入力データとし ての位置づけであり，実用上施工現場において，これら 一連の計算処理（パソコン程度）が可能であることが望 ましい.

本論文は, 山留め架構の構造モデルに対して逆定式化 が簡便にできる方法として，山留め壁に沿った深さ方向 に計測データを順次処理するアルゴリズムを提案した. そして，このアルゴリズムを基に，拉張カルマンフィル ターへの各種定式化法を示した。 そしてシミュレーショ ンによって求めた山留め壁の変位データを用い山留め壁 に作用する側圧等の推定を行い本方法の有効性を数値的 に明らかにした。

\section{EK-WGI 法5)}

拡張カルマンフィルター ${ }^{6}$ は，線形システムに対する 最適状態推定のカルマンフィルターに対して，より一般 的に非線形システムに対しても適用できるように拡張さ れたものである．拡張カルマンフィルターは，非確率関 数である規準軌跡を用いて線形化し，カルマンフィル ターとほぼ同様なアルゴリズムによって構成されてい る.

一般に拡張カルマンフィルターの基本式である非線形 の状態方程式および非線形の観測方程式は，それぞれ式

(1), 式 (2) のように示される.

$$
\begin{aligned}
& d X_{t} / d t=f\left(X_{t}, t\right)+G(t) w_{t} \\
& y_{t k}=h\left(X_{t k}, t_{k}\right)+v_{k} \cdots \cdots \cdots \cdots . .
\end{aligned}
$$

ただし， $X_{t}, X_{t k}$ :それぞれ連続型，離散型の状態べク
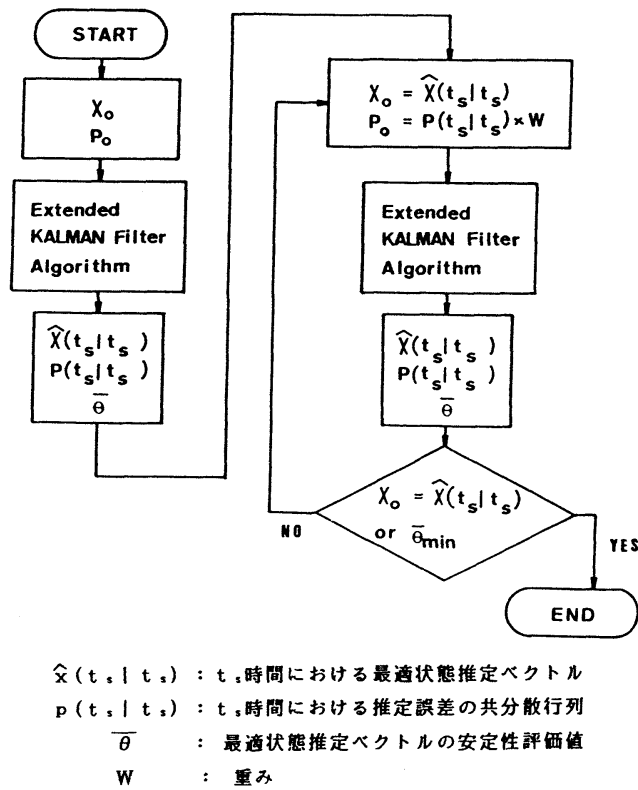

図一1ＥK-WGI 法のアルゴリズム

トル, $y_{t k}: t_{k}$ 時間での観測ベクトル, $w_{t}:$ 状態方程式 に付加されるガウス性ホワイトノイズ, $v_{k}$ : 観測方程式 に付加されるガウス性ホワイトノイズ, $G(t)$ : 変換行列, $X_{t 0}$ : 初期状態ベクトル (平均値 $X_{t 0}$, 分散值 $P_{t 0}$ のガウ ス分布)

そして初期状態ベクトル, 初期の推定誤差の共分散行 列およびノイズの分散が与えられれば，拡張カルマン フィルターは, 測定值 $y_{t k}$ を順次取り込みながら状態べ クトルの最適推定值を順次求めていくアルゴリズムであ る.

これに対して EK-WGI 法は, 拡張カルマンフィル ターのアルゴリズムを推定誤差の共分散行列に重みを乗 せながらグローバルに繰り返す方法で，各グローバルな 繰り返し時の推定結果の比較より推定結果の安定性を判 断して最適状態推定量を求めるものである（図一1）。

拡張カルマンフィルター基本式 (1) および ( 2 ) は, ダイナミックシステムを対象としていることから時間 $t$ による状態ベクトル $X_{t}$ の変化として定式化されてい る.ここでは, 位置 $x$ に対する状態べクトル $(Y)$ の変 化として読み替え定式化を行った.

\section{3. 定式 化}

山留め架構は, 弾性床上のはりとしてモデル化される のが一般的である ${ }^{7), 8)}$. 図一2 は, $k$ 次掘削終了時の山 留め架構モデルを示したもので, $g_{s}(x)$ を掘削面以浅の 背面側側圧と切ばり軸力によるモーメント, $g_{B}(x)$ を掘 削面以深の背面側側圧とすると, 


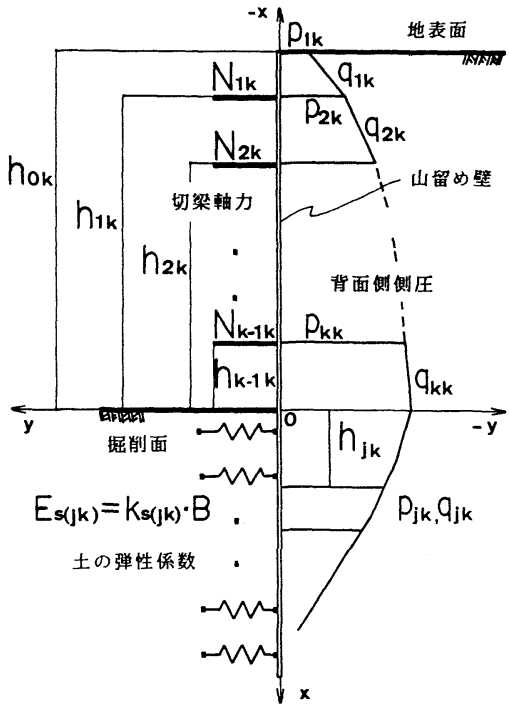

図一2 $k$ 次掘削時の山留め架構モデル

地表面一掘削面間に対して

$E I\left(d^{2} y / d x^{2}\right)=g_{s}(x)$.

また掘削面以深に対しては

$E I\left(d^{4} y / d x^{4}\right)+E_{s} y=g_{B}(x)$

ここで $E_{s}:$ 土の横方向弾性係数

$E$ : 山留め壁の弾性係数

$I$ ：山留め壁の断面 2 次モーメント

$y$ : 山留め壁の変位

として示される.

図一2に示したように背面側側圧は，地表面〜掘削面 間に対して, 切ばり間で線形変化, また掘削面以深では, 要素間で線形変化するものと仮定し，また土の横方向弾 性係数は, 要素間で一定值であるものと仮定すると $k$ 次掘削時に対して ${ }^{9)}$

$$
\begin{aligned}
& N_{k-2, k} \sim N_{k-1, k} \text { 間の } g_{s}(x) \text { は } \\
& g_{s}(x)= \sum_{i}^{k-1}\left[(1 / 6)\left\{3 p_{i, k}+q_{i, k}\left(h_{i-1, k}-h_{i, k}\right)\right\}\left\{h_{i-1, k}-h_{i, k}\right\}^{2}\right. \\
&+(1 / 2)\left\{2 p_{i, k}+q_{i, k}\left(h_{i-1, k}-h_{i, k}\right)\right\}\left\{h_{i-1, k}-h_{i, k}\right\} \\
&\left.\cdot\left\{h_{i, k}+x\right\}\right]+(1 / 6)\left\{3 p_{k, k}+q_{k, k}\left(h_{k-1, k}+x\right)\right\} \\
& \cdot\left\{h_{k-1, k}+x\right\}^{2}-\sum_{i}^{k-1} N_{i, k}\left(h_{i, k}+x\right) \cdots \cdots \cdots \cdots(5)
\end{aligned}
$$

ただし，

$N_{i, k}: k$ 次掘削時の $i$ 番目の切ばり位置の軸力

$p_{i, k}: k$ 次掘削時の $i-1$ 番目の切ばり位置の背面側 側圧（ $i=1$ では，地表面位置での背面側側圧）

$q_{i, k}: k$ 次掘削時の $i-1$ 番目切ばり位置 $i$ 番目切 ばり位置間の背面側側圧の変化率

$h_{i, k}: k$ 次掘削時の掘削面から $N_{i, k}$ の切ばり軸力位置 までの距離
また $j$ 区間の $g_{B}(x)$ は

$$
g_{B}(x)=q_{j, k}\left(x+h_{j, k}\right)+p_{j, k}
$$

として示される.

さて式（3）および（4）の拡張カルマンフィルター

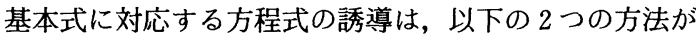
考えられる9). すなわち

1. 式（3）および（4）の微分方程式を状態空間表 示を用い, 1 階のベクトル微分方程式に変換し式

（1）に対応する状態方程式として定式化する方法

2. 式（3）および（4）の微分方程式の一般解を求 め式（2）に対応する観測方程式として定式化する 方法である.

\section{（1）微分方程式を用いた定式化}

式（3）に対しては, $y=y_{1}, y^{(1)}=y_{2}\left(\right.$ ただし,$\left.y^{(1)}=d y / d x\right)$ として状態空間表示すると

$$
\left\{\begin{array}{l}
y_{1} \\
y_{2}
\end{array}\right\}^{(1)}=\left[\begin{array}{ll}
0, & 1 \\
0, & 0
\end{array}\right]\left\{\begin{array}{l}
y_{1} \\
y_{2}
\end{array}\right\}+\left[\begin{array}{ll}
1, & 0 \\
0, & 1
\end{array}\right]\left\{\begin{array}{c}
0 \\
g_{s}(x) / E I
\end{array}\right\}
$$

ただし，状態ベクトル $Y=\left[y_{1}, y_{2}\right]^{T}$ の ${ }^{(1)}$ の表示は $x に$ 関する 1 階微分である.

として示され, 式（1）の右辺 1 項までの 1 階のベクト ル微分方程式が得られる.

次に式（4）に対しては

$$
y=y_{1}, \quad y^{(1)}=y_{2}, \quad y^{(2)}=y_{3}, \quad y^{(3)}=y_{4}
$$

と状態空間表示すると

$$
\left.\left|\begin{array}{l}
y_{1} \\
y_{2} \\
y_{3} \\
y_{4}
\end{array}\right\rangle^{(1)}=\left[\begin{array}{llll}
0, & 1, & 0, & 0 \\
0, & 0, & 1, & 0 \\
0, & 0, & 0, & 1 \\
\alpha, & 0, & 0, & 0
\end{array}\right] \mid \begin{array}{l}
y_{1} \\
y_{2} \\
y_{3} \\
y_{4}
\end{array}\right\}
$$

$$
\left.+\left[\begin{array}{llll}
1, & 0, & 0, & 0 \\
0, & 1, & 0, & 0 \\
0, & 0, & 1, & 0 \\
0, & 0, & 0, & 1
\end{array}\right] \mid \begin{array}{c}
0 \\
0 \\
0 \\
g_{B}(x) / E I
\end{array}\right\}
$$

ただし $\alpha=E_{s} / E I$

として示される。

そして, 式（7）および（８）の状態ベクトルに対して 末知パラメーターベクトルを直列に並べることにより， 未知パラメーターを含んだ最適状態量推定問題とな $る^{6)}$.

次に式（7）および（8）に対応する観測方程式を示 す. 本推定法は, 山留め壁の変位または, 傾斜角デー夕 を壁の深さ方向にシーケンシャルに処理し最適状態推定 量を順次求めるものである.

地表面一掘削面間では, $N_{i-1, k} \sim N_{i, k}$ 区間の変位また は，傾斜角データから $p_{i, k}, q_{i, k}$ および切ばり軸力 $N_{i-1, k}$ を推定するもので，それ以浅の $p, q$ および切ばり軸力 
$N$ はすべて推定されているものとする.

ここで, 山留め壁の変位データが計測されているもの とすると, 式 (7) に対応する観測方程式は, 以下に示 す線形の観測方程式となる.

$$
\{y\}=[1,0,0,0,0]\left|\begin{array}{c}
y_{1} \\
y_{2} \\
p_{i, k} \\
q_{i, k} \\
N_{i-1, k}
\end{array}\right|
$$

また掘削面以深では, 任意区間 $j$ 間の山留め壁の変位 または傾斜角に対して $E_{s(j, k)}, p_{j, k}$ および $q_{j, k}$ を推定す るものとする.

前述と同様に, 山留め壁の変位デー夕が計測されるもの とすると, 観測方程式は,

$$
\{y\}=[1,0,0,0,0,0,0] \quad \begin{gathered}
y_{1} \\
y_{2} \\
y_{3} \\
y_{4} \\
p_{j, k} \\
q_{j, k} \\
E_{s(j, k)}
\end{gathered} \mid
$$

\section{として示される.}

\section{（2）微分方程式に一般解を用いた定式化}

ここでは, 式（3）および（4）の一般解を求め拡張 カルマンフィルターの基本式に定式化を行う方法を示 す. 式 $(3)$ の一般解は, $g_{s}(x)$ が $x$ に関して $n$ 次の多 項式で表現される場合には, 変位 $y$ は, $n+2$ 次の多項 式として示される.

図-2では，背面側側圧に対して 1 次式として仮定して おり, 変位 $y$ は 5 次の多項式として示される.すなわ ち

$$
\begin{aligned}
y= & a_{0(i, k)}+a_{1(i, k)} x+a_{2(i, k)} x^{2}+a_{3(i, k)} x^{3}+a_{4(i, k)} x^{4} \\
& +a_{5(i, k)} x^{5} \ldots \ldots \ldots \ldots \ldots \ldots \ldots \ldots \ldots \ldots \ldots \ldots \ldots \ldots \ldots \ldots \ldots \ldots \ldots \ldots \ldots \ldots \ldots \ldots \ldots \ldots \ldots \ldots
\end{aligned}
$$

ただし， $a_{0(i, k)} \sim a_{5(i, k)}: N_{i-1, k} \sim N_{i, k}$ 区間の未定係数

3. (1) と同様に山留め壁の変位が計測されている場 合には，切ばり間の状態方程式および観測方程式は，以 下のように定式化できる.

$$
\begin{aligned}
& \left|\begin{array}{c}
a_{0(i, k)} \\
a_{1(i, \kappa)} \\
\cdot \\
\cdot \\
a_{5(i, k)}
\end{array}\right|^{(1)}=\left[\begin{array}{l} 
\\
0 \\
\cdot \\
a_{5(i, k)}
\end{array} \mid\right. \\
& y=\left[1, x, x^{2}, \cdots, x^{5}\right]\left|\begin{array}{c}
a_{0(i, k)} \\
a_{1(i, k)} \\
\cdot \\
\cdot \\
a_{5(i, k)}
\end{array}\right|
\end{aligned}
$$

次に式 (4) の一般解は

$$
\begin{aligned}
y= & e^{\beta x}\left(c_{1} \cos \beta x+c_{2} \sin \beta x\right) \\
& +e^{-\beta_{x}}\left(c_{3} \cos \beta x+c_{4} \sin \beta x\right) \\
& +g_{B}(x) /\left(4 E I \beta^{4}\right) \\
\beta= & \sqrt[4]{E_{s} /(4 E I)}
\end{aligned}
$$

$$
\text { として示される. }
$$

$k$ 次掘削 $j$ 区間において変位が測定されている場合には 式（2）の観測方程式に対応する定式化は,

$$
\begin{aligned}
& y=e^{A_{i, k x} x}\left(c_{1(i, k)} \cos \beta_{(i, k)} x+c_{2(i, k)} \sin \beta_{(i, k)} x\right) \\
& +e^{-\boldsymbol{\beta}_{i, k} x}\left(c_{3(i, k)} \cos \beta_{(i, k)} x+c_{4(i, k)} \sin \beta_{(i, k)} x\right) \\
& +g_{B}(x) /\left(4 E I \beta_{(i, k)}^{4}\right)
\end{aligned}
$$

また式 (1) の状態方程式は, $\beta_{(i, k),}, c_{1(i, k)} \sim c_{4(i, k)}$ およ び式（6）の $p_{j, k}, q_{j, k}$ を末知パラメーターとすると

$$
\left|\begin{array}{c}
c_{1(i, k)} \\
c_{2(i, k)} \\
c_{3(i, k)} \\
c_{4(i, k)} \\
\beta_{(i, k)} \\
p_{j, k} \\
q_{j, k}
\end{array}\right|^{(1)}=\left[\quad 0 \quad\left|\begin{array}{c}
c_{1(i, k)} \\
c_{2(i, k)} \\
c_{3(i, k)} \\
c_{4(i, k)} \\
\beta_{(i, k)} \\
p_{j, k} \\
q_{j, k}
\end{array}\right|\right.
$$

として示される.

なお, 弾性床上のはりモデルによる山留め架構の応力 計算では，一般に地盤の非線形性を弾塑性として考慮し ている.すなわち，掘削面以深の掘削側は，受働土王を 越えた反力を生じた場合には, 塑性状態であるものとし， 受働土圧に置き換えて作用させ, 再度応力計算を行う. そしてこの繰り返し計算により, 収束する弾塑性境界深 さを求め計算を終了させ, 山留め壁の変位, 応力および 切ばり軸力値を算定する.

ここでのパラメーター推定では, 塑性域に対しても特 別な定式化および計算は行わず，上述に示した定式化を 用いた。

\section{4. 計 算 例}

ここでの計算例は, 推定結果の検証のため, シミュレー ションにより求めた山留め壁の変位デー夕を用い, 未知 パラメーターの推定を行った. そして得られた推定パラ メーターと, シミュレーションに用いた入力条件等との 比較より，本方法の有効性を数值的に明らかにした。

(1) シミュレーションモデル

シミュレーションモデルは, 図一3に示したように掘 削深度 $\left(h_{03}\right)=9.2 \mathrm{~m}$ の 3 次掘削終了時とした. 山留め壁 は, 弾性係数 $E=2.1 \times 10^{7} \mathrm{tf} / \mathrm{m}^{2}$, 断面 2 次モーメント $I=5 \times 10^{-4} \mathrm{~m}^{4}$ の無限長の弾性体とした. 掘削面以浅の 背面側側圧分布は, $B \eta\left(h_{03}+x\right)$ と仮定し, その係数 $\eta$ の值を $0.9 \mathrm{tf} / \mathrm{m}^{3}$ とした. また受働土圧分布は $B(\xi x+\zeta)$

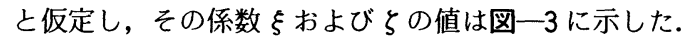




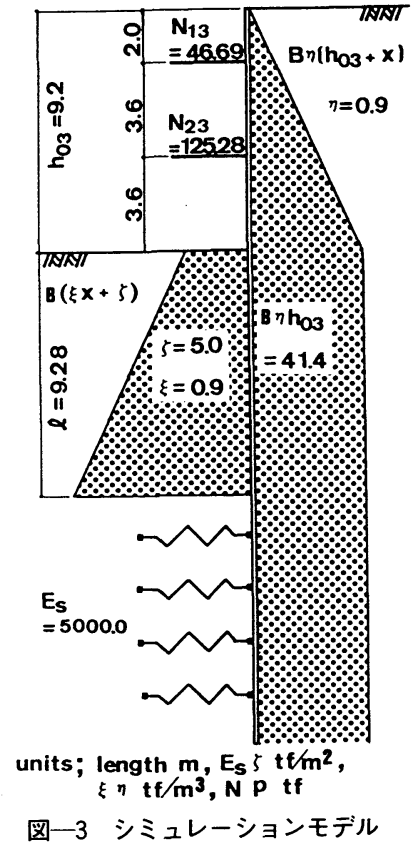

なお, $B$ は, 切ばり水平間隔 $(5 \mathrm{~m}), x$ の原点は, 掘 削面である。

計算は，文献 7）による方法を用いた。計算によって 求めた切ばり軸力 $N_{1,3}, N_{2,3}$ および弾塑性境界深さ $l$ は

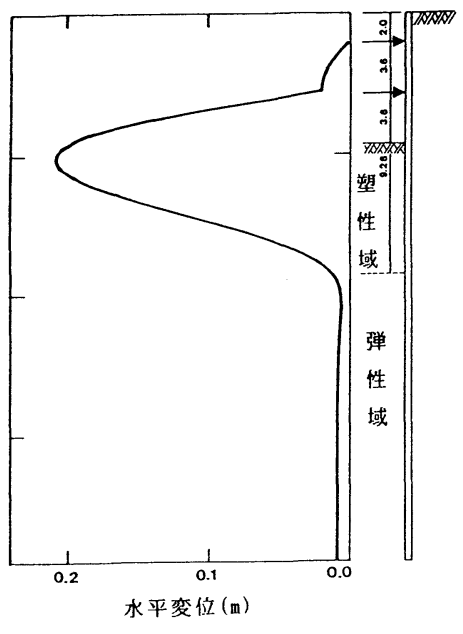

図一4 山留め壁の変位分布

図一3中に示した。また図一4 は, 計算によって求めた 山留め壁の変位分布を示したもので, この分布を次節に 示す未知パラメーター推定計算 (逆解析) に用いる計测 データとした.

\section{（2）推定結果}

図一5 の口内は, 推定結果である. 地表面〜掘削面間 の切ばり軸力および側圧は, 以下の方法により推定した. まず, $p_{13}, q_{13}$ の推定は, 地表面〜 1 段切ばり位置まで

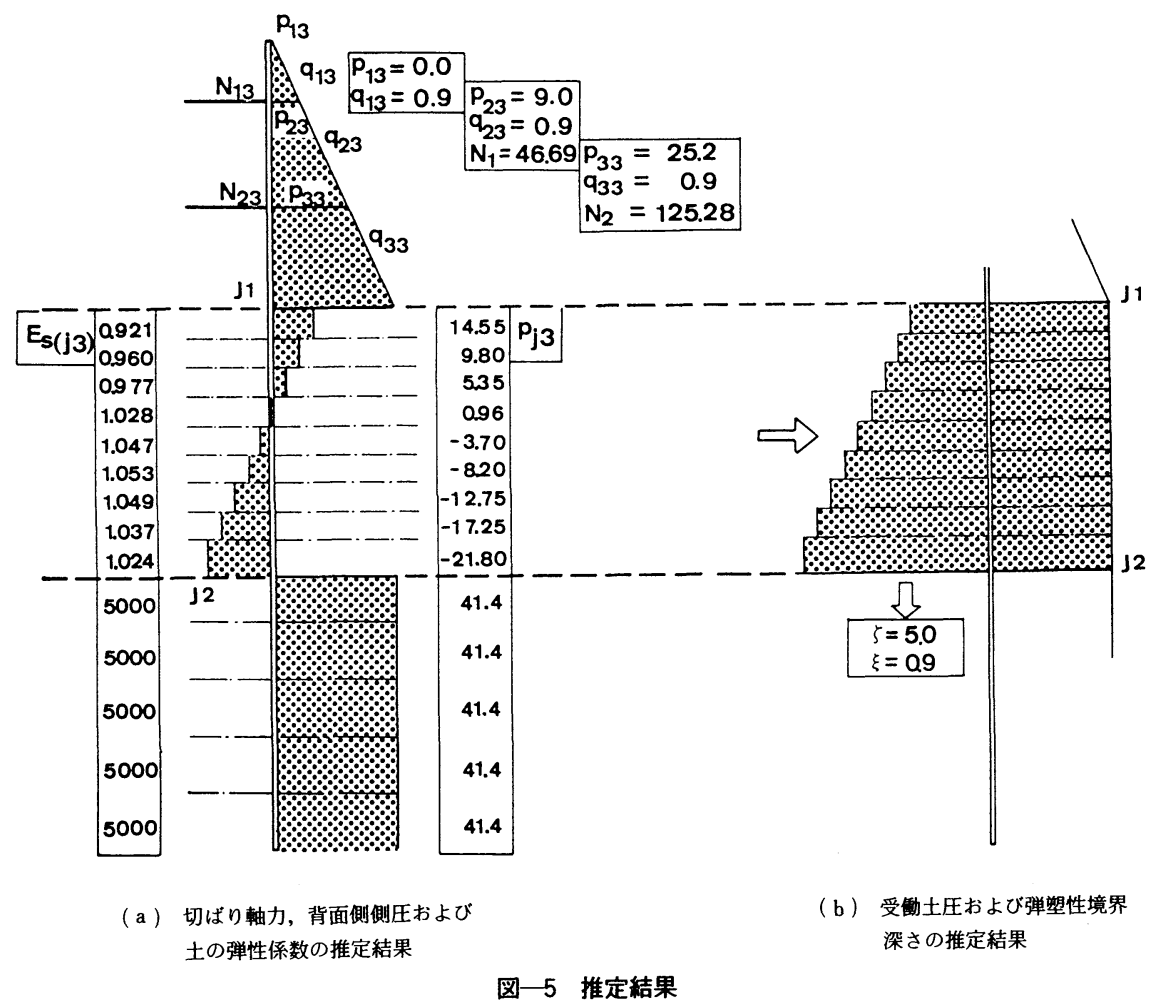


のデー夕から推定する. そして推定した $p_{13}, q_{13}$ を既知 量として，1 段切ばり〜2 段切ばり間のデータより側圧 $p_{23}, q_{23}$ および軸力 $N_{1,3}$ を推定する．以上の方法により 順次側圧および切ばり軸力の推定を行った.これらの推 定結果は, シミュレーションによって求めた（図一-3） 切ばり軸力および入力条件の側圧（図一3）と比較する と非常によい精度で推定できることがわかる。なお $p_{23}, p_{33}$ の値は, 入力条件として $B \eta\left(h_{03}+x\right)$ の分布形状 であるから，それぞれ 9.0 および 25.2 となる.

掘削面以深については，任意区間に計測データを区分 し土の横方向弾性係数 $E_{S(j 3)}$ および側圧 $p_{j 3}$ の推定を順 次行うと図一 $5(\mathrm{a})$ の結果が得られた。 $E_{\text {s(j3) }}$ の值は, J 1 ～J 2 区間ではほぼ同様な值（1.0 程度）となり，それ 以深では，急激に大きな值となる $(5000.0)$. また $p_{j 3}$ の值は J 1 J 2 区間で徐々に減少し (14.55 - 21.80) それ以深では一定値 $(41.4)$ となる. $E_{s(j)}$ および $p_{j 3}$ の $\mathrm{J} 2$ 位置以深の一定值は, 掘削面以深の弾性域での入 力条件とそれぞれ等しくなることがわかる. 背面側の推 定された側圧および推定された土の弾性係数の分布形状 より，J1〜J 2 区間では，不連続な分布形状となること がわかり，この区間では，地盤の状態がその他の範囲と 異なるものと考えられる。この範囲は，シミュレーショ ンにより求めた弾塑性境界深さ $l$ とほぼ一致することが わかり，推定された $E_{\left.s_{(j)}\right)}$ および $p_{j 3}$ は背面側側圧と受 働側圧を等価に置き換えた值であるものと考えられる。 次に J 1 J 2 区間は，塑性状態であるものとして塑性域 の未知パラメーター $\xi$ およ゙ $ら$ の推定を試みる. 掘削 面以深から推定された J 1 位置の值および弾性域から推 定された $\mathrm{J} 2$ 位置の值が，掘削面以深から推定された $\mathrm{J} 1$ 位置の值および掘削面以深の塑性域から推定された $\mathrm{J} 2$ 位置の値と等しいものと仮定して J 1 J 2 区間の背 面側側圧を求めると図一5(b) のようになる．そして背 面側とつり合う側圧を掘削側の J $1 \sim \mathrm{J} 2$ 区間に重社合せ をすると，図一5(b) の分布形状となり，これから推定 される受働土圧の推定值 $\xi$ および $\zeta$ はシュレーショ ンに用いた入力条件 $\xi=0.9, \zeta=0.5$ とよい一致を示す ことがわかる.

以上のように弾塑性境界深さ $l$ の判断も繰り返し計算 を行うことなく可能であることがわかる．また弾性域で の $E_{s(j)}$ および $p_{j 3}$ の推定結果も, 入力条件で用いた值 とよい一致を示すことがわかる.ここでのシミュレー ションデータの深さ方向のデータピッチは, $0.1 \mathrm{~m}$ とし た。なお掘削面以深では，本方法を用いる場合特に深さ 方向のデータピッチを細かくする必要がある.

以上の推定結果は, EK-WGI 法を用いれば, 3. (1) および 3. ( 2 ) の定式化方法とも同様な精度の結果が得 られた。なお，これら 2 方法の定式化の数値計算上の留
意点は,

3. ( 1 ) の定式化に対して

式 (7) および式（8）の状態方程式の行列指数関数 の展開式による離散化は，一般に右辺第 2 項の入力項が データ区間で一定であるとした仮定のもとに定式化され ている ${ }^{10)}$.この離散化を用いて推定された各パラメー タ一值は, 上述に示した推定結果より精度はよくなかっ た。 上述に示した推定結果は, 式（7）に対して $x$ 方 向の $y^{(4)}$ がデー夕区間で線形変化するとした仮定のもと で，テーラー展開により離散化し ${ }^{11)}$ ，また式（8）に対 しては, 入力項がデー夕区間で線形変化の仮定のもとに 行列指数関数の展開式により離散化し, それぞれ求めた ものである.

3. ( 2 ) の定式化に対して

式（15）を用いたパラメーター同定では， $\beta_{(h, k)}$ の初期 条件の与え方により最適状態推定ベクトル值が発散現象 を生じてしまうことがある. 数値的には明確に示せない が, $\beta_{(L, k)}$ の初期値は小さな值がよいものと思われる. である.

\section{5. おわりに}

本論文は, 掘削に伴い山留め壁に生ずる変位の計測 データから,壁体に作用する側圧等を,拡張カルマンフィ ルターを基本式とした EK-WGI 法を用いて推定する方 法を示したものである.これらの推定值は, 次段階の掘 削に対する予測計算に用いる重要な入力条件となる。こ こでは, まず山留め架構の構造モデルを一般的な応力計 算に用いられている弾性床上のはりとしてモデル化し, 拡張カルマンフィルター基本式への 2 方法の定式化法を 示した. そしてこれらの 2 方法により, シミュレーショ ンにより求めた山留め壁の変位分布を用いて推定結果の 数値的な検討を行った．この変位分布を用いた場合，掘 削面以浅では，背面側側圧および切ばり軸力を，両定式 化とも精度よく推定できることが数值的に確かめられ た．また掘削面以梁では，背面側側圧および土の弾性係 数を掘削面以浅と同様に精度よく推定できることが明ら かになった．また掘削面以深の弾塑性境界深さおよび受 働土圧も上述の推定結果をもとに繰り返し計算等を用い ることなく図式的に求められることが数值的に明らかに なった。

なお現在，現場の実測デー夕を用いて，本方法により 側圧等の推定を行い, その適用性について検討を行って いる.

\section{参考文 献}

1) Terzaghi, K. and Peck, R.B. : Soil mechanics in engineering practice, John Wiley \& Sons, 1948.

2) Gioda, G. : Some remarks on back analysis and charac- 
terization problems in geomechanics, Fifth International Conferance on Numerical Methods in Geomechanics, Nagoya, April, 1985.

3）富永・越後・橋本・木村：RCC システムの開発について (第 2 報)，第 12 回土質工学研究発表会, 1977.

4）丸岡・青木・幾田・佐藤 : 山留め観測施工法に関する研 究 (その 1), 第 19 回土質工学研究発表会, 1984.

5）星谷・斉藤：拡張カルマンフィルターを用いた同定問題 の各種振動系への応用, 土木学会論文報告集, 第 339 号, 1983.

6) Jazwinski, A.H. : Stochastic Processes and filtering theory, Academic Press, 1970.
7）山肩・吉田・秋野 : 掘削工事における切バリ土留め機構 の理論的考察, 土と基礎, 17-9, 1969.

8）中村·中沢 : 掘削工事における土留壁の応力解析, 土 質工学論文報告集, Vol.12, No.4, Dec., 1972.

9) 斉藤・山県ほか：拡張カルマンフィルターによる山留め 設計パラメータの推定 (その 4)一定式化の改良一, 土木 学会第 40 回年次学術講演会概要集, 1985.

10）高橋安人：システムと制御, 岩波書店, 1978.

11）斉藤・山県ほか：拡張カルマンフィルターによる山留め 設計パラメータの推定, 第 20 回土質工学研究発表会, 1985.

(1986.8.4 • 受付) 